\title{
THE EFFICIENCY OF ZAKAH INSTITUTIONS USING DATA ENVELOPMENT ANALYSIS
}

\author{
Aam Slamet Rusydiana, Salman Al-Farisi
}

\begin{abstract}
The Efficiency of Zakah Institutions Using Data Envelopment Analysis. Although social based, but in its management the Zakah Institutions need to uphold professionalism, transparency and accountability. Most recently, in the measurement of the effectiveness of the management of zakah fund, known Zakah Core Principles concept. This study would try to measure the efficiency of 3 (three) Zakah Institutions with Data Envelopment Analysis (DEA) method. Banxia Frontier Analyst 3.1 used in data calculation. The calculation of the level of Zakah Institutions efficiency in this study are relative, not absolute. The results show that there is 12 fully efficient Decision Making Unit (DMU) Zakah Institution (100\% efficient) and 6 DMU inefficient. The main factor inefficiency Zakah Institution from 2007 to 2014 due to the distribution of zakah funds to ashnaf. It is still less than optimal. So it has not been able to resolve the problem of poverty.
\end{abstract}

Keywords: zakah institution; efficiency; data envelopment analysis; poverty

\begin{abstract}
Abstrak. Efisiensi Institusi Zakat Menggunakan Data Envelopment Analysis. Meskipun berbasis pada kegiatan social, namun manajemen dari organisasi pengelola zakat tetap mengharuskan kegiatan yang menjunjung tinggi profesionalisme, transparansi, dan akuntabilitas. Saat ini pengukuran efisiensi manajemen pada organisasi pengelola zakat dikenal dengan konsep prinsip inti zakat. Penelitian ini bertujuan untuk mengukur tingkat efisiensi pada tiga organisasi pengelola zakat dengan menggunakan data envelopment analysis. Alat bantu yang dipergunakan ialah Banxia Frontier Analyst versi 3.1. Pengukuran tingkat efisiensi organisasi zakat pada penelitian ini bersifat relatif dan bukan absolut. Hasil menunjukkan bahwa terdapat 12 unit pengambilan keputusan pada organisasi pengelola zakat yang beroperasi pada tingkat yang efisien dan enam unit pengambilan keputusan yang tidak efisien. Faktor utama inefisiensi pada organisasi pengelola zakat rentang waktu 2007 sampai dengan 2014 disebabkan oleh distribusi dana zakat pada ashnaf. Hal ini masih jauh dari optimal. Hal ini menjadikan zakat belum mampu menjadi solusi dalam pengentasan kemiskinan.
\end{abstract}

Kata Kunci: organisasi pengelola zakat; efisiensi; data envelopment analysis; kemiskinan 


\section{Introduction}

Zakah is a stimulus in the economy, which raises new force in the accumulation of a significant investment that would boost the production of the economy cycle in the region. Even the macro side, zakah would be able to increase an aggregate demand due to increase purchasing power of community for goods and services. When zakah implemented by good governance system, in the sense zakah is the binding regulations in every Muslim with the government's role as a regulator as well as the zakah board, then it would be trigger to the emergence of job opportunity, in order every citizen has a job and the migration of unemployment would happen to employees in a large number automatically. Zakah also has a main role in the creation of justice in the economic field, in which all citizens have a source of revenue and income to fulfill daily needs for their life. Zakat can give the contribution for alleviating the poverty through the zakah multiplier effect (Al Arif, 2010).

In management of the use of zakah funds, the most important is the role of amil zakah (read: Zakah Institution) as bearers of the trust in management of the zakah funds. If the amil zakah is good in its management, then eight of zakathreceipts (ashnaf) will be good anyway. But if the amil zakah is not good in its management, it should not be expected to ashnaf will be good too, that is essence of the amil zakah strategic. In other words, the most important thing of zakah is how to manage the use of zakah funds (management).

Zakah Institution (OPZ) is the intermediary organizations based on social. The entire of operating expense is taken from the zakah and infaq funds collected. It is also justified by Sharia, because OPZ committee is Amilin zakah that also included in eight ashnaf eligible for Zakah. The portion used for operation activities and Amilin's salaries (Akbar, 2009). The portion of amil zakah is not exceed that $12,5 \%$ from the all collected funds (Al Arif, 2010)

Although OPZ based on social activities, but the management is still needs to uphold professional, accountability, and transparency principles. Include in this term, OPZ need to operate effectively and efficiently. Most recently, in the measurement of the effectiveness of zakah management, Zakah National Board (Baznas) in cooperation with Bank Indonesia initiates the concept of Zakat Core Principles (Beik, et.al, 2014).

In measuring the degree of efficiency, Data Envelopment Analysis (DEA) is preferable. DEA is widely used to measure the level of technical efficiency, scale of economic and industrial banks and financial institutions. This is suitable according to research of Kamarudin, et.al (2008); Ozdemir (2013); Shahreki (2012); Tsolas and Dimitris (2012). But in this time, DEA also used in measuring the efficiency of non-bank institutions, such as hospitals, universities, tax offices, and including 
nonprofit institutions (Rusydiana, 2013).

The research related to the efficiency of zakah institution has done by several researchers. For example by Wahab et al. (2012) and (2013), Noor (2015) and (2012) and Ahmad (2014). But all of research is based in Malaysia. Only Akbar (2009), that makes OPZ in Indonesia as an object of research. This study would try to measure $\mathrm{OPZ}$ as Decision Making Unit (DMU) in the level of efficiency. And also the research would look at the possibility of potential improvement from inefficient OPZ, inputoutput contribution and the reference contribution of the DMU. Therefore, based on the background described above, the formulation of the problem in this study would try to answer the questions as follows: First, from the DMU objects studied, Which OPZ has been efficient and not efficient? Second, in general, how about total potential improvement of OPZ studied? Three, how does the analysis of Return to Scale (RTS), Reference Frequencies and Input-Output Contribution of OPZ?

\section{Literature Review}

The concept of efficiency come from the microeconomic concept, namely, consumer theory and producer theory. Although the producer theory more concerned with the concept of efficiency compared with consumer theory. Consumer theory tries to maximize utility or satisfaction from individual point of views, while producer theory tries to maximize profit or minimize costs from producer point of views. In the producer theory, there is a production frontier line that describes the relationship between inputs and outputs of production process. This production frontier line represents the maximum output from the use of each input. It also represents the technology used by a business unit or industry. A business unit that operates on the production frontiers is technically efficient. The figure below shows the production frontier line.

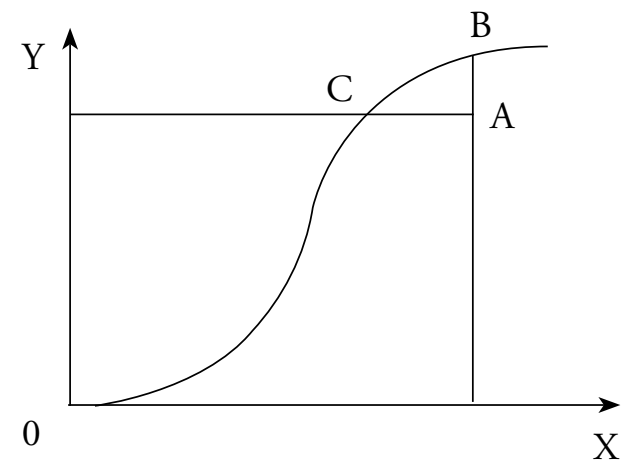

Figure 1. Production Frontier 
Efficiency comprises of two components, namely: first, technical efficiency describes the ability of a business unit to maximize output given certain amount of input; and second, allocative efficiency describes the ability of a business unit to utilize inputs in optimal proportion based on their price. When the two types of efficiency combined, it will produce economic efficiency. A company is considered to be economically efficient if it can minimize the production costs to produce certain output within common technology level and market price level (Farell, 1957).

Kumbhaker and Lovell (2000) argue that technical efficiency is only one of many components economic efficiency as a whole. Nevertheless, in order to achieve economic efficiency a company should produce maximum output with certain amount of input (technical efficiency) and produce output with the right combination within certain price level (allocative efficiency).

In the past few years, performance measurement of financial institution has increasingly focused on frontier efficiency or X-efficiency (rather than scale efficiency), which measures deviation in performance of a decision making unit from the best practices or costs-efficient frontier that depicts the lowest production costs for a given level of output. X-efficiency stems from technical efficiency, which gauges the degree of friction and waste in the production process, and allocative efficiency, which measures the levels of various inputs.

Frontier efficiency is superior for most regulatory and other purposes to the standard financial ratios from accounting statements, such as, return on asset (ROA) or cost/revenue ratio, that are commonly employed by regulators, managers of financial institutions, or industrial consultants to assess financial performance. This is because frontier efficiency measures use programming or statistical techniques that removes the effects of differences in input prices and other exogenous market factors affecting the standard performance ratios in order to obtain better estimates of the underlying performance of the managers (Bauer, et al., 1998).

The study on zakah institution efficiency measurement has done by Akbar (2009). This study aims to determine the level of efficiency of Zakah Institutions in Indonesia using DEA with the production approach. This method measures the ratio between output and input, which are compared between the studied OPZ. Output variables used are fund collected and channeled fund, while its inputs are personnel costs, socialization costs and other operational costs. The results show that the efficiency of OPZ in the year 2005 is still better than in 2006 and 2007, both technically (94.52\%), scale (75\%), and overall (71.27\%). Calculation of nine OPZ in 2007 with the assumption of CRS, shows only 2 OPZ efficient, ie, BMM and Bamuis BNI. The main cause of inefficiency is channeled fund and fund collected, which contributed $43.1 \%$ and $36 \%$. While the input-oriented measures states that 
the source of inefficiency is the other operational costs (34.9\%) and the cost of socialization $(31.1 \%)$.

Study done by Norazlina and Abdul Rahim (2012), is to analyze the efficiency of zakah institutions in Malaysia by using data envelopment analysis (DEA) method to estimate zakah efficiency and Tobit model to determine the efficiency of zakah institution in Malaysia. Technical efficiency, pure technical efficiency and scale efficiency of DEA model being used. The empirical findings suggest that zakah payment, computerized zakah system, board size, audit committee and decentralization significantly affect the efficiency if zakah institutions in Malaysia. The analysis showed that fully corporatized zakah institutions are positively associated with efficiency of zakah institutions in Malaysia while partially corporatized negatively affect zakah efficiency.

Norazlina \& Abdul Rahim (2011), in their framework to analyse the efficiency and governance of zakah institutions by using the DEA. They argued that the characteristics of DEA are suitable for application to zakat institutions, as it was successfully applied as indicator for efficiency of non-profit and public sectors. Further, Norazlina \& Abdul Rahim (2012) measure the productivity growth of zakat institutions by using the variable returns to scale (VRS) and they found that most of zakah institutions were operating at non-CRS (Constant Return Scale) . Thus, they need more improvements by zakah institutions to improve the overall of efficiency. However, in their work, their study of efficiency seemed to focus on technical efficiency and scale efficiency.

Nur Hafizah and Selamah (2013) analyze the profile of zakah collection institutions and the efficiency of the institutions in collecting the zakah by using Data Envelopment Analysis (DEA) approach. The study conducted in the three states of Federal Territories including Kuala Lumpur, Putrajaya and Labuan. The results of the efficiency found that all of the three areas of zakah institutions are efficient. The overall finding indicate that the center managed by Federal Territories maintain their performance and able not only to increase the total of zakah collections but also number of new and existing zakah payers.

Zakah institution is a non-profit organization in its functionality. Berber et al. (2011) suggested a two stage DEA analysis in measuring the efficiency of nonprofit organization. The stage one measures the efficiency of fund-raising and the stage two measures the delivery of service (in our case the distribution of zakat to the beneficiaries). The output of stage one is included in the input of stage two. Berber et al. (2011) found that the separation of the fundraising function from product delivery function will show a clearer analysis of efficiency, as both efforts of fund raising and service delivery or distribution are equally important. 


\section{Methods}

Tools to measure efficiency could be parametric and non-parametric. Parametric approach to measuring efficiency uses stochastic econometric and tries to eliminate the impact of disturbance to inefficiency. There are many parametric econometric approaches. Three of them namely: 1) Stochastic frontier approach (SFA); 2) Thick frontier approach (TFA); and 3) Distribution-free approach (DFA). These approaches differ in the assumptions they make regarding the shape of the efficient frontier, the treatment of random error, and the distributions assumed for inefficiencies and random error.

This study applies Data Envelopment Analysis (DEA) method. DEA is a nonparametric method to measure the relative efficiency of production frontier based on the multiple inputs and outputs of decision making unit, in this case, zakah institution. The non-parametric nature of DEA makes it require no assumption of the production function and the DEA approach will generate the production function based on observed data, so the misspecification can be minimized. DEA can be applied to analyze different kind of inputs and outputs without initially assigning weight. Moreover, the efficiency produced is a relative efficiency based on observed data. The preference of the decision maker can also be accommodated in the model.

Methodology used in this study is a nonparametric Data Envelopment Analysis (DEA) with the production approach. DEA is a method of measuring the efficiency based input-output (Coelli (1998). Cooper et al (1999) and Farrell (1957)). The variable output of the DMU consisting of Total Deposits Zakat (Y1) and Total Fund Distribution (Y2), while the input variables comprised of Personnel Costs (X1), Operating Expenses (X2), and Socialization Cost (X3). DEA score will be derived from these variables, which is the result of dividing the output and input factors (Charnes, Cooper and Rhodes, 1978).

Data Envelopment Analysis is a methodology for analyzing the relative efficiency and managerial performance of decision-making unit (DMU). The DEA allows us to compare the relative efficiency of DMU by firstly determine the efficient DMU as benchmarks and then measure the inefficiencies in input combinations (slack variables) of other DMU relative to the benchmark. DEA is a mathematical programming technique that measures the efficiency of a decision-making unit (DMU) relative to other similar DMUs with the simple restrictions that all DMUs lay on or below the efficiency frontier (Cooper et.al, 2002). The performance of a DMU is very relative to other DMUs, especially those that cause inefficiency. This approach can also determine how a DMU can improve its performance to become efficient. 
From the set of available data, the DEA identifies the reference points as relatively efficient DMUs then define the efficient frontier as the best practice production technology and finally evaluate the inefficiencies of other interior points. All the inefficient DMUs will lies below the efficient frontier. Besides producing efficiency value for each DMU, DEA also determines DMUs that are used as benchmark for other inefficient DMU.

$$
\text { Efficiency of } D M U_{o}=\frac{\sum_{K=1}^{p} \mu_{k} \mathrm{y}_{k 0}}{\sum_{i=1}^{m} v_{i} x_{i 0}}
$$

DMU = decision making unit $\quad \mathrm{n} \quad=$ number of DMU evaluated

$\mathrm{m} \quad=$ different inputs $\quad \mathrm{xij}=$ number of input $\mathrm{i}$ consumed by DMUj

$\mathrm{p} \quad=$ different outputs $\quad \mathrm{ykj}=$ number of output $\mathrm{k}$ produced by DMUj

DEA Model is two, BCC and CCR. BCC model developed by Banker, Charnes and Cooper (1984), while CCR model developed by Charnes, Cooper and Rhodes (1978). Both differ in their treatment on the return to scale (RTS). The $\mathrm{BCC}$ assumes each DMU can operate with variable return to scale (VRS), while the CCR model assumes each DMU operates with constant return to scale (CRS). Generally, the efficiency rating of CCR model for each DMU will not exceed the BCC model. This is because the BCC model analysis each DMU "locally", compared to the subset of DMUs that operate in the same region of return to scale, rather than "globally" (Jemric and Vujcic, 2002). The BCC model represents technical efficiency only, while the CCR model represents the multiplication of pure technical and scale efficiencies.

The Study in this research focused on measuring the efficiency level of three OPZ. There are Zakah National Board (Baznas), Pos Keadilan Peduli Umat (PKPU) and Rumah Zakat Indonesia (RZI). The reason for selection of the OPZ, because it publishs its annual financial statements relative consistently. And also, Baznas, PKPU and RZI are quite managed to raise substantial funds from the public. This study uses secondary data for 2007-2014 that was published as basic data, such as financial reports, balance sheet and cash flow statement. Data can be obtained from the publications issued by each OPZ. However, due to limited data available, Baznas data is only from 2007-2013 and RZI 2012-2014. While PKPU data is relatively complete from the period 2007-2014. 


\section{Result and Discussion}

\section{Efficiency Score of Zakah Institution}

In Table 1, OPZ that included to efficient (Constant 100\%) in 2014 was PKPU. While OPZ that included to efficient in 2013 was Baznas. Furthermore, it can be seen that PKPU was efficient over the years, from 2007 to 2014, except in 2013, PKPU include to inefficient. This shows that in the period 2007-2014, PKPU is able to maintain the level of efficiency gradually (except in 2013) when compared with other OPZ. Based on the explanation, the lowest efficiency of OPZ is RZI in 2013.

Table 1. Efficiency Score of Zakat Institutions

\begin{tabular}{cccc}
\hline No & Name & Score & Scale \\
\hline 1 & 2007 Baznas & 100 & Constant \\
2 & 2008 Baznas & 100 & Constant \\
3 & 2009 Baznas & 100 & Constant \\
4 & 2012 Baznas & 100 & Constant \\
5 & 2008 PKPU & 100 & Constant \\
6 & 2007 PKPU & 100 & Constant \\
7 & 2011 PKPU & 100 & Constant \\
8 & 2012 PKPU & 100 & Constant \\
9 & 2009 PKPU & 100 & Constant \\
10 & 2013 Baznas & 100 & Constant \\
11 & 2010 PKPU & 100 & Constant \\
12 & 2014 PKPU & 100 & Constant \\
13 & 2013 PKPU & 98.13 & Increasing \\
14 & 2012 Rumah Zakat & 76.14 & Increasing \\
15 & 2010 Baznas & 58.74 & Decreasing \\
16 & 2014 Rumah Zakat & 57.21 & Increasing \\
17 & 2011 Baznas & 55.07 & Decreasing \\
18 & 2013 Rumah Zakat & 54.89 & Increasing \\
\hline
\end{tabular}

This is able to be a consideration for other OPZ that has not been efficient in order to improve the technical efficiency. In addition, the DMU (OPZ) is inefficient divided into two parts, both Increasing Return to Scale (IRS) and Decreasing 
Return to Scale (DRS). The OPZ included in the increasing group, such as PKPU (2013), RZI (2012), RZI (2013), and RZI (2014). To achieve an efficient level of each OPZ that include to inefficient, it can be cultivated with a view of its potential improvement. Unlike the case with OPZ which included in decreasing group, such as Baznas (2010) and (2011).

\section{Distribution of Efficiency Score}

Information based on the previous table, the graph below provides information on the number of business units (DMU) are efficient and inefficient on a scale of a particular group. Based on the following chart can know the number of efficient OPZ $(100 \%)$ was as much as $12 \mathrm{OPZ}$. The graph below also provides information that most business units are in efficiency $100 \%$, namely 12 DMU, while the least DMU with the level of efficiency of $71-80 \%$ and $91 \%-99.9 \%$, every single level is 1 DMU.

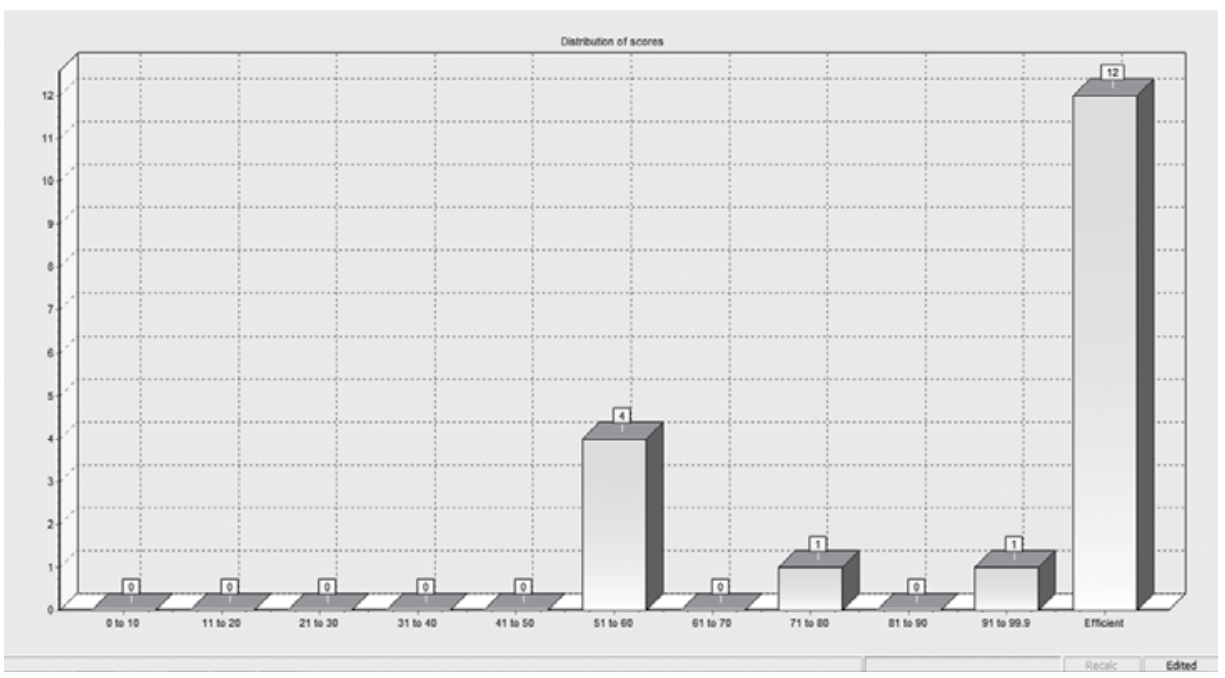

Figure 2. Distribution of Efficiency Score

\section{Total Potential Improvement of Zakah Institutions}

To find out the source of inefficiency from OPZ in these observations, it can be seen through the total potential improvement in the information below to provide a general overview associated with OPZ that include to inefficient. Graph of total potential improvement mention that, in order efficient, inefficient OPZ should reduce cost of SDM to $13.89 \%$, in addition, socialization cost until $8.16 \%$ and operating costs to $8.02 \%$. While for the revenue fund needs to be increased up to $0.93 \%$ and the fund distribution to $69 \%$ in order to achieve optimal efficiency levels. 


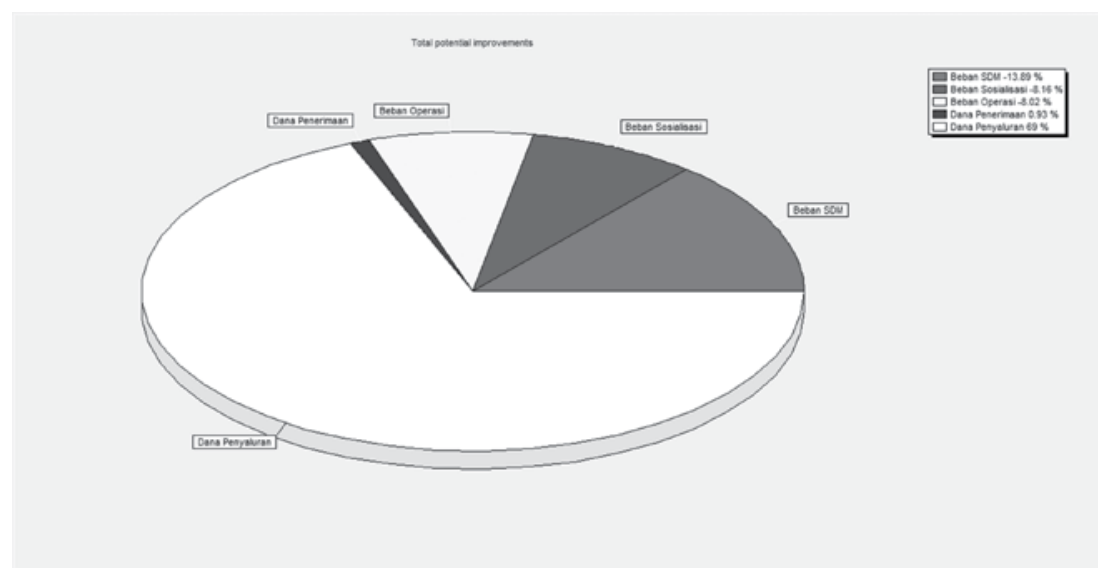

Figure 3. Total Potential Improvement

\section{Reference DMU}

This section explains about OPZ as the reference to other OPZ is still inefficient. From the calculation of frontier analysis shows that in 2014 Zakah Institution (OPZ) most referenced is PKPU, referenced by 4 DMU. Whereas in 2013, OPZ most referenced is Baznas, referenced by 4 DMU. Unlike the case in 2012, OPZ most referenced are Baznas, referenced by 2 DMU and PKPU as much as 1 DMU. In 2011, OPZ most referenced is PKPU, referenced by 3 DMU. In 2010, PKPU is referenced by 1 DMU. About the year 2009, OPZ most referenced is PKPU as much as 3 DMU, and Baznas referenced by 1 DMU. As well as in 2008, OPZ most referenced is PKPU as much as 4 DMU and Baznas referenced by 1 DMU.

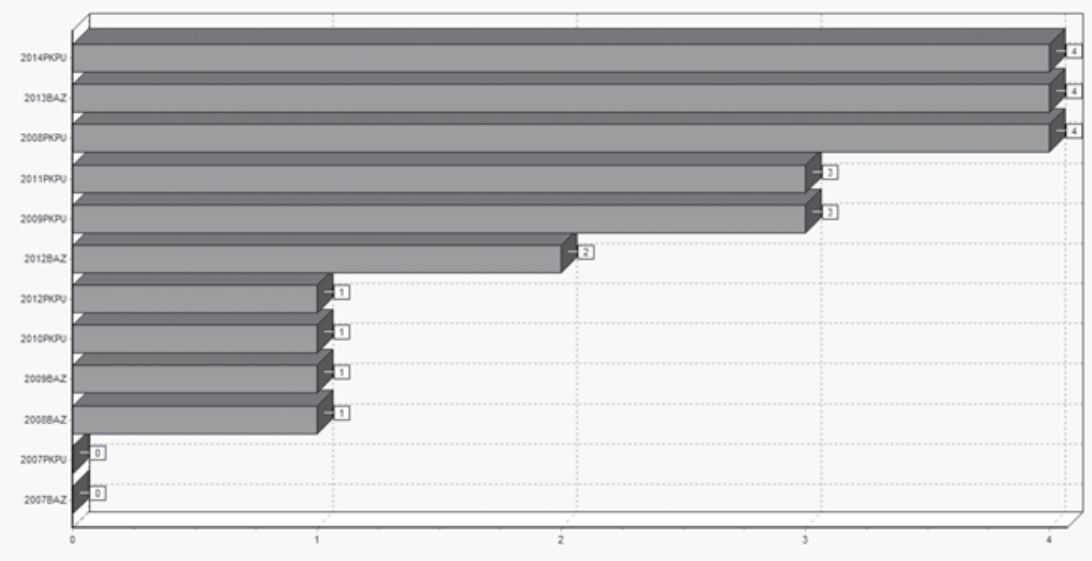

Figure 4. Reference Frequencies 


\section{Analysis of Inefficient DMU}

This section describes the potential improvement from the lowest efficiency level of OPZ that is RZI (2013). According to the first unit detail graphics on the top left side, explained that in order to achieve the level of efficiency, RZI (2013) has to reduce operating expenses to $45 \%$, socialization cost to $45 \%$, and SDM cost to $85 \%$. In addition, it needs to improve the distribution of funds up to $649 \%$.

In the next chart (on the top right) about the reference comparison of RZI (2013) shows that, to achieve a level of optimum efficiency, RZI (2013) may be referring to three OPZ referenced are Baznas (2013), PKPU (2014), PKPU (2009). For example, when compared RZI (2013) with Baznas (2013), the use of operating cost, Baznas (2013) amounted to $19 \%$, the use of socialization cost is $21 \%$, and SDM cost was at $43 \%$ with distribution fund amounted to $521 \%$ and revenue fund by $65 \%$.

Then, in the third graph about the chart of input/output contribution is explained that the level of efficiency of RZI (2013) amounted to $54.89 \%$. Which contribute greatly to the efficiency of RZI (2013) in achieving an efficiency of 54.89\% are operational costs by $71 \%$, socialization cost amounted to $29 \%$, and revenue fund amounted to $100 \%$. This indicates that the operating costs, socialization cost and revenue fund have contributed to achieve the efficiency rate of RZI (2013) amounted to $54.89 \%$.

Furthermore, the last chart about the reference contribution chart, it explains the contribution of each business unit was referred by the RZI (2013). Based on the chart below, the nearest business unit (DMU) which can be referenced by RZI to five variables (input and output) are Baznas (2013), and was followed by PKPU (2009) and the last is PKPU (2014).

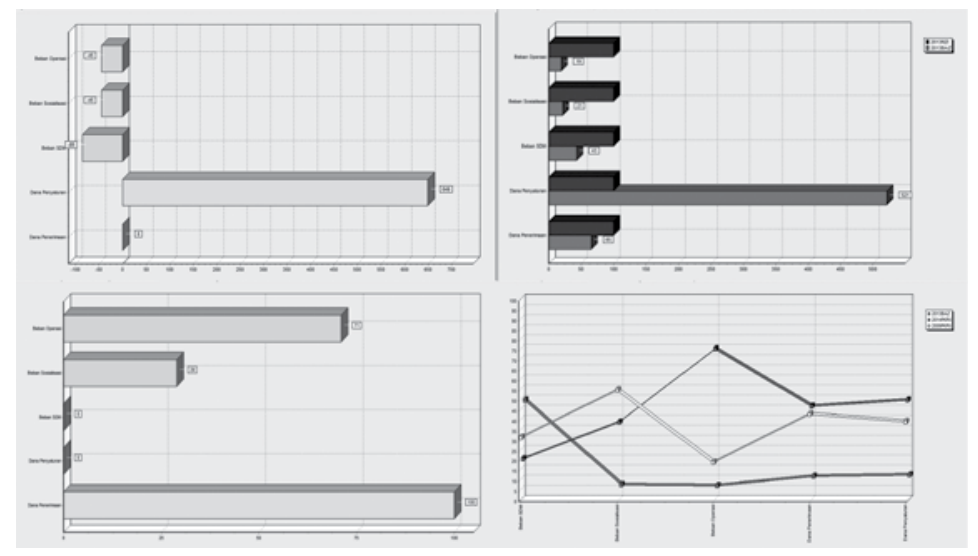

Figure 5. Unit Details: RZ 2013 


\section{Conclusion}

Research on efficiency of Zakat Institution is important to do. Here are some of the conclusions that can be drawn the following recommendation for future research. There are $12 \mathrm{DMU}$ that efficient (100\%) and inefficient as much as 6 DMU. OPZ most inefficient is RZI (2013). OPZ PKPU is able to maintain the level of efficiency gradually from 2007 to 2014 (except in 2013) when compared with other OPZ. In general, the main factor inefficiency of Zakat Institution from 2007 to 2014 due to the distribution of zakat funds to ashnaf is still less optimal, so it has not been able to resolve the problem of poverty. The need for every Zakah Institution (OPZ) is to issue annual financial statements in order to increase accountability and transparency in the management of funds. The ultimate goal is improvement and development of zakat and OPZ in Indonesia. Zakah Institutions, both public and private sector need to do the counting of efficiency levels routinely and regularly so that it knows the level of efficiency, potential improvement and it's benefit and weakness in general, within the framework of efficiency analysis. Due to limited data that the authors obtained, the number of observations is small relatively.

\section{References}

Ahmad, I. \& M. Ma'in. (2014). The Efficiency of Zakat Collection and Distribution: Evidence from Two Stage Analysis. Journal of Economic Cooperation and Development. Vol. 35 (3): 133-170.

Akbar, N. (2009). Analisis Efisiensi Organisasi Pengelola Zakat Nasional Dengan Pendekatan Data Envelopment Analysis. Tazkia Islamic Finance and Business Review. Vol. 4 (2): 201-210.

Al Arif, M.N.R. (2010). Ekonomi Makro Islam. Bandung: Alfabeta.

Al Arif, M.N.R. (2010). Efek Pengganda Zakat Serta Implikasinya Terhadap Program Pengentasan Kemiskinan. Jurnal Ekbisi. Vol. 5 (1): 42-49.

Banker, R.D. et.al. (1984). Some Models for Estimating Technical and Scale Inefficiency in Data Envelopment Analysis. Management Science. Vol. 30 (9): 1078-1092.

Berber, P. et.al. (2011). Efficiency in Fundraising and Distributions to Cause-related Social Profit Enterprises. Socio-Economic Planning Sciences. Vol. 45: 1-9.

Bauer, P.W. et.al. (1998). Consistency Conditions for Regulatory Analysis of Financial Institutions: A Comparison of Frontier Efficiency Methods. Financial Services Working Paper, 02/97, Federal Reserve. 
Beik, I.S. et al. (2014). Towardss an Establishment of an Efficient and Sound Zakat System: Proposed Core Principles for Effective Zakat Supervision. Paper presented in the Working Group of Zakat Core Principles 2014.

Charnes, A. et.al. (1978). Measuring the Efficiency of Decision Making Units. European Journal of Operation Research. Vol. 2 (6): 429-44.

Coelli.T.I. et.al. (2005). Introduction to Efficiency and Productivity Analysis. Boston: Kluwer Academic Publisher.

Cooper, W.W. et.al. (1999). A Comprehensive Text with Models, Application, References and DEA-Solver Software. Boston: Kluwer Academic Publisher.

Cooper, et al. (2002). Data Envelopment Analysis. Boston: Kluwer Academic Publisher.

Cooper, W.W. et.al. (2010). Handbook on Data Envelopment Analysis. London: Springer.

Farrell, M.L. (1957). The Measurement of Productive Efficiency. Journal of The Royal Statistical Society. Vol. 120: 253-281.

Jemric, I. \& B. Vujcic. (2002). Efficiency of Banks in Croatia: A DEA Approach. Working Paper 7 February 2002. Croatian National Bank.

Kamarudin. et.al. (2008). Assessing Production Efficiency of Islamic Banks and Conventional Bank Islamic Windows in Malaysia. International Journal of Business and Management Research. Vol. 1 (1):. 31-48. 2008.

Noor, A.H.M. et al. (2012). Assessing Performance of Nonprofit Organization: A Framework for Zakat Institutions. British Journal of Economics, Finance and Management Sciences. Vol. 5 (1): 71-80

Noor, A.H.M.et al. (2015). Efficiency of Islamic Institutions: Empirical Evidence of Zakat Organizations Performance in Malaysia. Journal of Economics, Business and Management, Vol. 3 (2): 181-190.

Ishak, N.H. \& S. Maamor (2013). Kajian Kecekapan Kutipan Zakat di Wilayah Persekutuan. Proceding PERKEM VIII. Jilid 1: $414-425$.

Ozdemir, A. (2013). Integrating Analytic Network Process and Data Envelopment Analysis for Efficiency Measurement of Turkish Commercial Banks. Banks and Bank Systems. Volume 8 (2): 201-210.

Rusydiana, A.S. \& Tim SMART Consulting. (2013). Mengukur Tingkat Efisiensi dengan Data Envelopment Analysis. Bogor: SMART Publishing.

Shahreki, J. et.al. (2012). Efficiency Evaluation Bank Sepah Branches in Sistan and Baluchestan Province Using Data Envelopment Analysis. Interdisciplinary Journal of Contemporary Research in Business. Vol. 4 (2): 191-200. 
Tsolas, I.E. \& D.I. Giokas. (2012). Bank Branch Efficiency Evaluation by Means of Least Absolute Deviations and DEA. Managerial Finance. Vol 38 (8): 511520.

Wahab, N.A. \& A.R.A. Rahman. (2011). A Framework to Analyze the Efficiency and Governance of Zakat Institutions. Journal of Islamic Accounting and Business Research. Vol. 2 (1): 43-62.

Wahab, N.A. \& A.R.A. Rahman. (2012). Efficiency of Zakat Institutions in Malaysia: An Application of Data Envelopment Analysis. Journal of Economic Cooperation and Development. Vol. 33 (1): 95-112.

Wahab, N.A. \& A.R.A. Rahman. (2013). Determinants of Efficiency of Zakat Institutions in Malaysia: A Non-parametric Approach. Asian Journal of Business and Accounting. Vol. 6 (2): 171-180. 